\title{
Meningkatkan Hasil Pembelajaran Bahasa Indonesia Materi Menganalisis Kebahasaan Teks Prosedur melalui Penerapan Model Pembelajaran Cooperative Learning
}

\author{
I Wayan Sudirta ${ }^{1 *}$ \\ ${ }^{1}$ SMA Negeri 1 Negara, Jembrana, Indonesia
}

\author{
A R T I C L E I N F O \\ Article history: \\ Received 09 February \\ 2021 \\ Received in revised form \\ 20 March 2021 \\ Accepted 08 April 2021 \\ Available online 11 May \\ 2021 \\ Kata Kunci: \\ Hasil Belajar, dan \\ Cooperative Learning. \\ Keywords: \\ Learning Outcomes, and \\ Cooperative Learning
}

\begin{abstract}
A B S T R A K
Rendahnya hasil belajar bahasa Indonesia siswa menjadi permasalahan utama didalam penelitian ini, sehingga diperlukan model pembelajaran yang dapat memotivasi siswa untuk belajar. Tujuan penelitian ini adalah untuk menganalisis hasil pembelajaran bahasa indonesia materi menganalisis kebahasaan teks prosedur melalui penerapan model pembelajaran Cooperative Learning siswa kelas XI. Penelitian ini termasuk kedalam jenis penelitian tindakan kelas (PTK). Subjek Penelitian ini adalah siswa kelas XI sebanyak 30 orang siswa. Metode pengumpulan data yang digunakan adalah pemberian tes hasil belajar kepada siswa secara bertahap yaitu siklus I dan Siklus II. Hasil penelitian ini berdasarkan penerapan model pembelajaran Cooperative Learning adalah diperoleh nilai rata-rata kelas 77,2 , ketuntasan belajar mencapai $83 \%$ pada siklus I, dan nilai rata-rata 82 , ketuntasan belajar mencapai $100 \%$ pada siklus II. Simpulan penelitian ini adalah dengan menerapkan model pembelajaran Cooperative Learning pada mata pelajaran bahasa Indonesia dapat meningkatkan hasil belajar siswa kelas XI.IPS SMA
\end{abstract} Negeri 1 Negara tahun pelajaran 2018/2019. Implikasi penelitian ini adalah mestimulus siswa untuk lebih aktif, lebih semangat dalam belajar serta keterlibatan siswa dalam kegiatan belajar mengajar lebih tinggi, siswa akan lebih cepat memahami materi pelajaran yang dibahas pada saat pembelajaran berlangsung dan tentu menyenangkan.

\begin{abstract}
A B S T R A K
The low learning outcomes of students in Indonesian is the main problem in this study, so a learning model is needed that can motivate students to learn. The purpose of this study was to analyze the results of Indonesian language learning materials to analyze the language of the procedural text through the application of the cooperative learning learning model for class XI students. This research belongs to the type of classroom action research (PTK). The subjects of this study were 30 students of class XI. The data collection method used was the provision of learning outcomes tests to students in stages, namely cycle I and cycle II. The results of this study based on the application of the Cooperative Learning learning model are obtained a class average score of 77.2, learning completeness reaches $83 \%$ in cycle I, and an average value of 82, learning completeness reaches $100 \%$ in cycle II. The conclusion of this research is that applying the Cooperative Learning learning model in Indonesian subjects can improve the learning outcomes of class XI IPS SMA Negeri 1 Negara in the 2018/2019 academic year. The implication of this research is that it encourages students to be more active, more enthusiastic in learning and higher student involvement in teaching and learning activities, students will more quickly understand the subject matter discussed during learning and of course it is fun.
\end{abstract}




\section{Pendahuluan}

Proses belajar mengajar merupakan kegiatan yang terpenting didalam keseluruhan proses pendidikan. Keberhasilan pencapaian tujuan pembelajaran bergantung pada kualitas proses belajar mengajar. Didalam prose belajar mengajar perlu dilakukan kegiatan penilaian untuk mengetahui tingkat keberhasilan suatu pembelajaran, sehingga diperlukan model pembelajaran yang dapat menambah semangat siswa untuk belajar (Amelia \& Saputra, 2017; Kurniasari, 2017; Mulyadin, 2016). Model pembelajaran merupakan kerangka strategi secara konseptual yang melukiskan prosedur yang sistematis dalam mengorganisasi prose pembelajaran yang berisikan langkah-langkah pembelajaran (Sari, 2017; Sukmady, 2017; Ulya et al., 2020). Penggunaan model pembelajaran yang kreatif dapat memotivasi siswa untuk belajar, sehingga berdampak pada hasil belajar, khususnya pada pembelajaran bahasa indonesia.

Berdasarkan hasil pengamatan pada tahap awal yang dilakukan Peneliti bahwa ditemukan masalah yaitu rendahnya hasil belajar mata pelajaran bahasa Indonsia yang dicapai siswa kelas XI.IPS pada semester ganjil tentang materi pelajaran menganalisis kebahasaan teks prosedur menjadi perhatian peneliti, karena hasil belajar siswa belum mencapai nilai sesuai dengan yang distandarkan sekolah dengan KKM 70 untuk mata pelajaran Bahasa Indonesia. Melihat kondisi demikian Peneliti merasa termotivasi untuk melakukan perbaikan-perbaikan melalui Penelitian Tindakan Kelas ini, dengan mewujudka keterampilan proses dan pembelajaran yang menekankan pada peran aktif siswa dalam belajar. Solusi yang diberikan oleh peneliti dengan penerapan model pembelajaran Cooperative Learning.

Model pembelajaran Cooperative Learning merupakan strategi pembelajaran yang menekankan peran aktif siswa belajar dikelas serta mampu menanamkan konsep atau prinsip yang sebelumnya tidak diketahuinya dan siswa akan lebih tekun dan asik serta menyenangkan karena dapat menarik perhatian siswa dalam belajar bahasa indonesia (Qusyairi \& Sakila, 2018; Sari et al., 2014; Sunanto et al., 2020). Sehingga, dapat membantu guru dalam upaya meningkatkan hasil belajar siswa untuk mata pelajaran bahasa indonesia. Pembelajaran dengan menggunakan model Cooperative Learning merupakan salah satu alternatif dan strategi yang tepat untuk mengatasi masalah membelajarkan siswa (Fitri et al., 2020; Ramadhani, 2017; Yuliarni et al., 2013). Model pembelajaran Cooperative Learning mampu mestimulus siswa untuk lebih aktif, lebih semangat dalam belajar serta keterlibatan siswa dalam kegiatan belajar mengajar lebih tinggi, siswa akan lebih cepat memahami materi pelajaran yang dibahas pada saat pembelajaran berlangsung dan tentu menyenangkan, sehingga dapat berpengaruh terhadap hasil akhir pembelajaran yaitu hasil belajar siswa (Aka, 2016; Darmawan, 2014; Said et al., 2019).

Hasil akhir atau hasil jangka panjang dari proses mengajar adalah kemampuan siswa yang tinggi untuk dapat belajar dengan mudah dan efektif di masa mendatang (Anggraeni et al., 2019; Suria et al., 2019; Yulia et al., 2019). Tekanan dari kegiatan mengajar tetap saja pada siswa yang belajar, jika dihubungkan dengan target mencapai ketuntasan yang diharapkan oleh seorang siswa dalam menguasai materi ideal yang ditetapkan dalam aturan standar nasional yaitu 75\%, maka dengan pencapaian nilai yang standar siswa akan merasa nyaman dalam mencapai prestasi sehingga perlu difasilitasi dalam belajar bahasa indonesia (Faizah, 2015; Putra et al., 2014; Putri et al., 2014).

Kegiatan pembelajaran mata pelajaran bahasa indonesia dengan materi menganalisis kebahasaan teks prosedur yang dilaksanakan di kelas XI.IPS semester ganjil SMA Negeri 1 Negara tahun 2018-2019. Diharapkan dapat memberi semangat dan lebih menyenangkan serta memperluas pemahaman konsep materi bahasa indonesia secara menyeluruh oleh siswa. (Asmahasanah et al., 2018; Larasati \& Gafur, 2018; Purwanti et al., 2014), menyatakan bahwa hakekat mengajar (teaching) adalah membantu siswa memperoleh informasi, ide, keterampilan, nilai, cara berfikir, sarana untuk mengekspresikan dirinya, dan cara-cara belajar bagaimana hal tersebut bisa tercapai.

Penelitian ini didukung dengan beberapa penelitian yang relevan dengan penelitian ini yaitu, pertama penelitian yang dilakukan oleh (Dewi, 2013), yang memperoleh hasil bahwa penggunakan Model Cooperative Learning teknik marry go round berpengaruh terhadap hasil belajar IPA siswa kelas IV SD. Kedua, penelitian yang dilakukan oleh (Darmawan, 2014), yang memperoleh hasil bahwa pembelajaran multimedia IPA berbasis animasi melalui model Cooperative Learning terbukti dapat meningkatkan kreativitas mahasiswa. Ketiga, penelitian yang dilakukan oleh (Aka, 2016), yang memperoleh hasil bahwa model quantum teaching dengan pendekatan Cooperative Learning terbukti dapat meningkatkan kualitas pembelajaran PKn.

Tujuan penelitian ini adalah untuk menganalisis hasil pembelajaran bahasa indonesia materi menganalisis kebahasaan teks prosedur melalui penerapan model pembelajaran Cooperative Learning siswa kelas XI.IPS semester ganjil SMA Negeri 1 Negara tahun pelajaran 2018/2019. 


\section{Metode}

Penelitian ini adalah penelitian tindakan kelas, maka metode yang digunakan adalah metoda deskriptif analisis hasil Penelitian Tindakan Kelas (PTK), yaitu studi yang digunakan untuk mengumpulkan data, mendeskripsikan, mengolah, menganalisa, menafsirkan dan menyimpulkan data sehingga diperoleh gambaran yang sistematis. Penelitian Ini dilakukan di SMA Negeri 1 Negara Tahun Pelajaran 2018/2019 dengan dengan alamat di Jl. Ngurah Rai No.155, Dauhwaru, Kec. Jembrana, Kabupaten Jembrana, Bali 82218

Penelitian dilaksanakan mulai dari Perencanaan sampai dengan penulisan laporan hasil Penelitian ini dimulai dari Bulan Juli s.d Desember tahun 2018. Pelaksanan Penelitian Tindakan Kelas ini dengan mengacu tindakan guru ketika melaksanakan kegiatan Belajar Mengajar sebagai upaya untuk memperbaiki kegiatan belajar mengajar berdasarkan refleksi dari kegiatan belajar mengajar tersebut. Oleh karena itu pelaksanaan penelitian ini Peneliti memfokuskan pada perbaikan hasil belajar siswa untuk mata pelajaran bahasa Indonesia sehingga perlu disediakan waktu yang cukup untuk memaksimalkan pelaksanaan Penelitian Tindakan Kelas ini.

Subjek Penelitian ini adalah siswa kelas XI.IPS Semester Ganjil SMA Negei 1 Negara sebanyak 30 orang siswa. Penelitian ini bertujuan untuk melihat peningkatan hasil belajar siswa pada mata pelajaran Bahasa Indonesia melalui penerapan model pembelajaran Cooperative Learning. Adapun dari jumlah siswa yang menjadi subjek tersebut sebanyak 30 orang teesebut didasari atas hasil belajar bahasa Indonesia yang dicapai siswa selama dilakukan pengamatan awal belum mencapai nilai standar yang ditentukan sekolah yaitu 78. Oleh karenanya Peneliti termotivasi untuk melakukan perbaikan-perbaikan agar hasil belajar siswa dapat ditingkatkan.

Pengumpulan data dalam Penelitian Tindakan Kelas ini dilakukan dengan menggunakan Instrumen Penelitian yang meliputi: (1) tes uji kompetensi; (2) angket siswa; (3) lembar observasi; (4) wawancara; (5) refleksi pembelajaran. Hasil yang didapat melalui penelitian tindakan kelas ini terutama pada tahap observasi dilakukan analisis oleh peneliti agar mendapat gambaran data dan informasi yang diperlukan untuk penulisan hasil penelitian ini lebih lanjut.

Teknik analisis data yang digunakan pada penelitian ini adalah analisis statistik kuantitatif berupa perhitungan data nilai siswa. Setelah data terkumpul dan diperiksa, bila memenuhi persyaratan, maka data tersebut dianalisis dan dihitung presentasenya. Sedangkan langkah-langkahnya adalah sebagai berikut: (1) mengumpulkan data; (2) menyeleksi data; (3) mengklasifikasi data; dan (4) menghitung prosentase.

\section{Hasil dan Pembahasan}

Pembahasan hasil Penelitian Tindakan Kelas pada mata pelajaran Bahasa Indonesia dengan materi menganalisis kebahasaan teks prosedur bagi siswa kelas XI.IPS Ssemester Ganjil SMA Negeri 1 Negara Tahun Pelajaran 2018/2019 yang diawali dengan tampilan data tes prasiklus. hasil tersebut diuraikan pada Tabel 1.

Tabel 1. Rangkuman Hasil prasiklus

\begin{tabular}{cccccccc}
\hline \multirow{2}{*}{$\begin{array}{c}\text { Jumlah } \\
\text { siswa }\end{array}$} & $\begin{array}{c}\text { Nilai } \\
\text { tertinggi }\end{array}$ & \multirow{2}{*}{$\begin{array}{c}\text { Nilai } \\
\text { terendah }\end{array}$} & \multirow{2}{*}{$\begin{array}{c}\text { Nilai } \\
\text { rata-rata }\end{array}$} & \multicolumn{2}{c}{ Siswa yang tuntas } & \multicolumn{2}{c}{$\begin{array}{c}\text { Siswa yang belum } \\
\text { tuntas }\end{array}$} \\
\cline { 5 - 8 } & & & kelas & Jumlah & Persen (\%) & Jumlah & Persen (\%) \\
\hline 30 & 80 & 55 & 67 & 11 & $37 \%$ & 19 & $63 \%$ \\
\hline
\end{tabular}

Berdasarkan hasil pra siklus diatas dapat di uraikan beberapa hal sebagai berikut: (1) sebanyak 11 orang siswa yang mendapat nilai rata-rata diatas KKM dengan katagori tuntas dalam mencapai peningkatan hasil belajar bahasa Indonesia; (2) sebanyak 19 orang siswa yang mendapat nilai rata-rata dibawah KKM dengan kata gori belum tuntas; (3) nilai rata-rata adalah 67, (4) ketercapaian ketuntasan belajar mencapai $37 \%$; (5) siswa yang belum truntas adalah $19 \%$.

Dari hasil pengamatan Peneliti pada prasiklus ini ditemukan atau di ungkap permasalahanpermasalahan yang ada pada siswa kelas XI.IPS Semester Ganjil SMA Negeri 1 Negara Tahun Pelajaran 2018/2019 yaitu: (1) tingkat kemampuan siswa dalam menganalisis kebahasaan teks prosedur rendah; (2) siswa nampak mengalami kesulitan dalam menganalisis unsur kebahasaan teks prosedur dengan tepat; (3) kemampuan dalam menganalisis untur kebahasaan teks porosedur belum didukung oleh penguasaan pengetahuan yanbg relevan dari siswa, karena siswa kurang banyak membaca literatur; (4) siswwa kurang mendapat kesempatan berlatih bahasa dengan baik; (5) siswa masih memerlukan 
bimbingan atau tuntunan dalam mencermati teks prosedur agar mampu memahami unsure kebahasaan teks prosedur dengan baik.

Berdasarkan permasalahan tersebut diatas, perlu dilakukan perbaikan dan melalui Penelitian Tindakan Kelas ini Peneliti akan melakukan perbaikan dari siklus, persiklus dengan melaksanakan tindakan refleksi bagi siswa yang belum mencapai nilai standar KKM/belum tuntas terhadap hasil belajar melalui penerapan model pembelajaran Cooperative Learning secara konsisten. Melihat kondisi yang demikian ini maka Peneliti berupaya memperbaiki kemampuan siswa pada aspek membaca mata pelajaran bahasa Indonesia dengan memberikan tindakan refleksi di setiap siklus jika hasil belajar siswa belum mencapai target pembelajaran maka tindakan dilakukan secara berkelanjutan sampai mencapai hasil maksimal.

Kegiatan pembelajaran pada siklkus I dilaksanakan sesuai dengan rencana pembelajaran yang telah disusun.Peneliti melaksanakan pengamatan terhadap hasil yang dicapai siswa pada prasiklus Setelah dilakukan identifikasi terhadap hasil yang dicapai pada prasiklus maka pada siuklus I dilaksanakan pembelajaran dengan menerapkan model pembelajaran Cooperative Learning. Gambaran perolehan nilai hasil belajar mata pelajaran bahasa Indonesia dengan materi menganalisis kebahasaan teks prosedur melalui penerapan model pembelajaran Cooperative Learning dijabarkan langkah demi langkah, sebagai upaya perbaikan hasil prasiklus. Sedangkan rangkuman hasil penelitian pada siklus I dapat dilihat pada Tabel 2 .

Tabel 2. Rangkuman hasil Siklus I

\begin{tabular}{cccccccc}
\hline \multirow{2}{*}{$\begin{array}{c}\text { Jumlah } \\
\text { siswa }\end{array}$} & $\begin{array}{c}\text { Nilai } \\
\text { tertinggi }\end{array}$ & $\begin{array}{c}\text { Nilai } \\
\text { terendah }\end{array}$ & $\begin{array}{c}\text { Nilai rata- } \\
\text { rata kelas }\end{array}$ & \multicolumn{2}{c}{ Siswa yang tuntas } & \multicolumn{2}{c}{$\begin{array}{c}\text { Siswa yang belum } \\
\text { tuntas }\end{array}$} \\
\cline { 5 - 7 } & & & & Jumlah & Persen (\%) & Jumlah & Persen (\%) \\
\hline 30 & 85 & 65 & 77,2 & 25 & $83 \%$ & 5 & $17 \%$ \\
\hline
\end{tabular}

Hasil siklus I dapat dideskripsikan sebagai berikut: (1) sebanyak 25 orang siswa yang mendapat nilai rata-rata diatas KKM dengan katagori tuntas dalam mencapai peningkatan hasil belajar Bahasa Indonesia dengan materi menganalisis kebahasaan teks prosedur; (2) sebanyak 5 orang siswa yang mendapat nilai rata-rata dibawah KKM dengan kata gori belum tuntas dalam meningkatkan hasil belajar bahasa indonesia dengan materi menganalisis kebahasaan teks prosedur; (3) nilai Rata-rata adalah 77,2; (4) ketercapaian ketuntasan belajar mencapai 25\%; (5) siswa yang belum tuntas $5 \%$.

Dari hasil pengamatan Peneliti pada siklus I ini ditemukan atau di ungkap beberapa hal yang ada pada siswa kelas XI IPS SMA Negei 1 Negara Semester ganjil Tahun Pelajaran 2018/2019 yaitu: (1) tingkat kemampuan siswa dalam memaknai konsep dari segi kebahasaan teks prosedur, telah terjadi peningkatan. pada siklus I; (2) pada Prasiklus nilai rata-yang dicapai siswa adalah 67 dengan ketuntasan belajar mencapai $37 \%$, sedangkan pada siklus I nilai rata-rata yang dicapai siswa adalah 77,2 , dengan ketuntasan belajar mencapai 83\%, terjadi peningkatan sebanyak 46\% di siklus I; (3) disamping hal tersebut siswa nampak mulai berani mengemukan tentang hasil analisis yang dicapai terhadap kebahasaan teks prosedur yang dipelajarinya; (4) dalam hal menentukan pola pengembanganm teks prosedur rata-rata siswa masih kurang dan memerlukan bimbingan dari guru yang lebih intensif; (5) guru telah melaksanakan pembelajaran dengan menerapkan model pembelajaran Coopoerative Learning secara konsisten dan berdampak terhadap hasil yang dicapai siswa; (6) siswa masih memerlukan bimbingan atau tuntunan dalam menganalisis secara tajam materi teks prosedur serta membuat laporan secara intensif, untuk mencapai hasil yang maksimal.

Berdasarkan permasalahan tersebut diatas, masih perlu dilakukan perbaikan dan melalui Penelitian Tindakan Kelas ini Peneliti di siklus II karena masih ada 5 orang siswa yang belum mencapai ketuntasan belajar di sikkus I. Berikut adalah grafik hasil penelitian siklus I dapat dilihat pada Gambar 1.

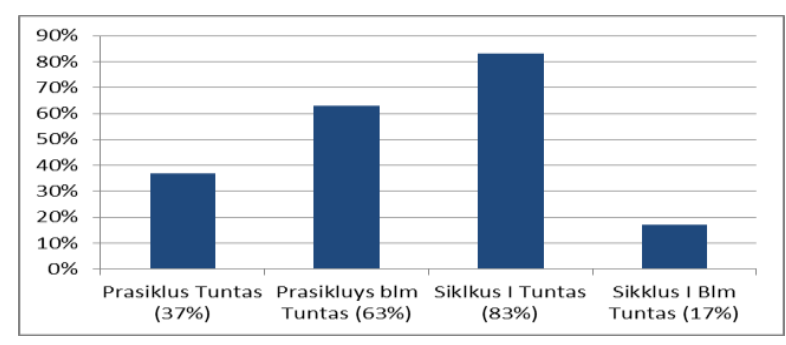

Gambar 1. Grafik Hasil Penelitian Siklus I 
Berdasarkan hasil post test pada siklus I yang dilanjutkan dengan refleksi hasil yang dicapai secara garis besar dapat ditunjukkan pada gambar grafik tersebut di atas dan menunjukkan bahwa terjadi peningkatan pada hasil belajar siswa di siklus I. Hal ini terbukti dari nilai post test siklus 1 yang lebih baik dari nilai tes sebelumnya (prasiklus). Ketuntasan belajar siswa juga mengalami peningkatan. Terbukti dengan meningkatnya ketuntasan belajar siswa dari 37\% (prasiklus) menjadi 83\% (siklus 1). Tetapi belum semua siswa dapat menuntaskan pembelajaran pada siklus I, masih terdapat 5 orang siswa yang belum menuntaskan pembelajaran pada siklus I sehingga pembahasan dilanjutkan pada siklus II.

Kegiatan pembelajaran siklus II dilaksanakan sesuai dengan renc ana yang telah disusun. Hasil belajar siswa yang dicapai pada siklus I menjadi acuan dalam melaksanakan pembelajaran di siklus II. Karena pada siklus II dilakukan perbaikan-perbaikan atas kekurangan yang terjadi pada siklus I, shingga diharapkan terjadi suatu peningkatan yang lebih baik. Berdasarkan hasil yang telah dicapai pada siklus I maka pada siklus II di dilakukan perbaikan terhadap 5 orang siswa yang belum mencapai ketuntasan belajar pada siklus I.

Pada siklus II siswa telah menunjukkan peningkatan hasil belajar yang baik dicapai selama pembelajaran berlangsung. Kegiatan bimbingan oleh guru dilakukan dengan konsisten dan mengacu pada kelemahan-kelemahan sebelumnya untuk dilakukan perbaikan. Siswa belajar dengan semangat yang tinggi serta berupaya untuk meningkatkan hasil belajar pada tingkat yang lebih baik. Berikut disajikan rangkuman hasil yang dicapai pada siklus II dapat dilihat pada Tabel 3.

Tabel 3. Rangkuman Analisa Data Hasil Prestasi Belajar Siswa Siklus II

\begin{tabular}{|c|c|c|c|c|c|c|c|}
\hline \multirow[t]{2}{*}{$\begin{array}{l}\text { Jumlah } \\
\text { siswa }\end{array}$} & \multirow[t]{2}{*}{$\begin{array}{l}\text { Nilai } \\
\text { tertinggi }\end{array}$} & \multirow[t]{2}{*}{$\begin{array}{c}\text { Nilai } \\
\text { terendah }\end{array}$} & \multirow{2}{*}{$\begin{array}{c}\text { Nilai } \\
\text { rata-rata } \\
\text { kelas }\end{array}$} & \multicolumn{2}{|c|}{ Siswa yang tuntas } & \multicolumn{2}{|c|}{$\begin{array}{c}\text { Siswa yang belum } \\
\text { tuntas }\end{array}$} \\
\hline & & & & Jumlah & Persen (\%) & Jumlah & Persen (\%) \\
\hline 30 & 90 & 70 & 82 & 30 & $100 \%$ & - & - \\
\hline
\end{tabular}

Berdasarkan hasil siklus II diatas dapat di uraikan beberapa hal sebagai berikut: (1) sebanyak 30 orang siswa yang mendapat nilai rata-rata diatas KKM dengan katagori tuntas dalam mencapai peningkatan hasil belajar pada mata pelajaran bahasa Indonesia dengan materi menganalisis kebahasaan teks prosedur; (2) sebanyak 30 orang siswa yang telah menuntaskan hasil belajar dalam meningkatkan hasil belajar mata pelajaran bahasa Indonesia dengan materi menganalisis kebahasaan teks prosedur; (3) nilai rata-rata adalah 82; (4) ketercapaian ketuntasan belajar mencapai 100 \%; (5) ketidak tuntasan siswa $0 \%$.

Dari hasil pengamatan Peneliti pada siklus II ini ditemukan atau di ungkap beberapa hal yang ada pada siswa kelas XI.IPS SMA Negeri 1 Negara pada Semester ganjil Tahun Pelajaran 2018/2019 yaitu: (1) tingkat kemampuan siswa dalam memaknai konsep materi teks prosedur untuk dilakukan analisis telah meningkat dengan baik sesuai harapan; (2) siswa sudah mampu melakukan analisis kebahasaan tekas prosedur melalui membaca dari segi kebahasaan, dalam pembelajaran bahasa indonesia dengan baik; (3) keberanian siswa dalam mengemukakan saran tentang sistematika dan struktur demikian juga ciri-ciri teks prosedur yang dipelajari melalui membaca, mengidentifikasinya jika masih ada yang belum tepat disampaikannya kepada guru dan guru memberikan bimbingan sesuai dengan permasalahan yang dihadapi oleh siswa; (4) siswa telah menunjukkan peningkatan hasil belajar yang sesuai dengan tujuan dari Penelitian Tindakan Kelas ini; (5) guru telah menggunakan model pembelajaran yang dapat menstimulus siswa agar lebih kreatif dalam belajar serta mempunyai rasa optimis yang tinggi untuk mencapai peningkatan hasil belajar mereka; (6) siswa telah menunjukkan kemampuan dalam mengkomunikasikan hasil pembelajaran bahasa Indonesia dalam kegiatan sehari-hari dengan baik.

Berdasarkan hal tersebut diatas, maka Penelitian Tindakan Kelas ini telah dinyatakan berhasil dan ketuntasan belajar telah mencapai $100 \%$. Pada siklus II ini tidak ada lagi siswa yang memperoleh nilai dibawah rata-rata atau tidak tuntas. Dari 30 orang siswa yang dijadikan subjek dalam Penelitian Tindakan Kelas ini telah berhasil dan tuntas dalam mencapai peningkatan hasil belajar telah dicapai oleh dsiswa kelas XI.IPS semester ganjil SMA Negeri 1 Negara Tahun pelajaran 2018/2019. Dengan demikian penerapan model pembelajaran Cooperative Learning dalam pembelajaran mata pelajaran Bahasa Indonesia dapat meningkatkan hasil belajar siswa. Adapun hasil yang diperoleh pada siklus II ini dapat disajikan Gambar 2. 


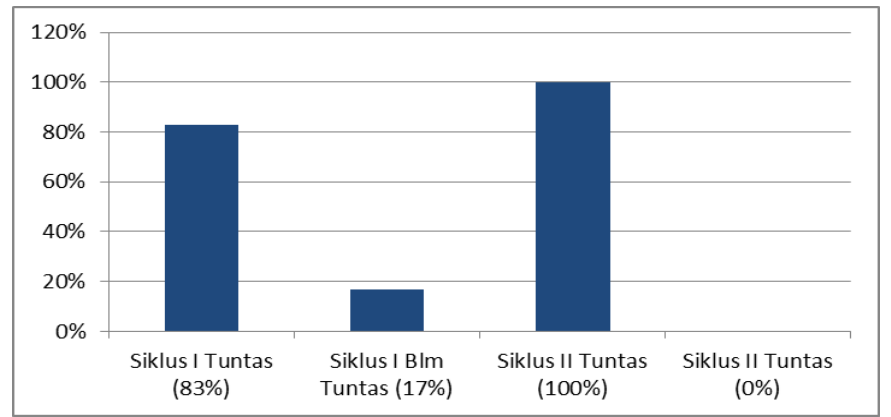

Gambar 2. Grafik Hasil Penelitian Siklus II

Dengan demikian pada siklus II seluruh siswa (30) orang siswa yang menjadi subjek dalam Penelitian Tindakan Kelas ini telah berhasil menuntaskan pembelajaran Bahasa Indonesia dengan materi menganalisis kebahasaan teks prosedur dengan optimal. Hal ini terbukti bahwa dengan penerapan model pembelajaran dengan menerapkan model cooiperative learning siswa dengan cepat dapat memahami materi bahasa Indonesia tentang materi menganalisis kebahasaan teks prosedur.

Hasil yang dicapai pada siklus I adalah meningkatnya hasil belajar siswa kelas XI.IPS pada semester ganjil SMA Negeri 1 Negara dan hal ini telah menunjukkan suatu bukti bahwa aktivitas dan pemahaman siswa terhadap materi pelajaran bahasa Indonesia tentang menganalisis kebahasaan teks Prosedur yang dilaksanakan dengan menerapkan model pembelajaran Cooperative Learning mengalami peningkatan pada siklus I.

Dari paparan hasil siklus I rata-rata nilai yanga dicapai siswa meliputi: (1) nilai rata-rata kelas adalah 77,2; (2) ketuntasan belajar mencapai 83\%; (3) siswa yang belum tuntas adalah 17\%; (4) peningkatan hasil pembelajaran ini dicapai karena peneliti menerapkan model pembelajaran Cooperative Learning dimana siswa diberi bimbingan secara kontinju sampai mencapai kemahiran dalam memahami, mengidentifikasi serta menganalisis kebahasaan teks prosedur yang dipelajarinya.

Pencapai hasil pada siklus II berdasarkan penerapan model pembelajaran Cooperative Learning, lebih diefektifkan pada siklus II. Bimbingan yang efektif mampu menstimulus siswa secara signifikan, sehingga mampu meningkatkan hasil belajar siswa dalam memaknai kebahasaan teks prosedur dan hasil belajar mata pelajaran bahasa Indonesia meningkat. Adapun jumlah nilai rata-rata pada siklus II ini adalah 82 dan ketuntasan belajar mencapai 100\%. Seluruh siswa (30) orang siswa telah mencapai ketuntasan belajar di Siklus II secara maksimal. Keseluruhan hasil yang telah dicapai dalam penelitian tindakan kelas ini dapat disajikan dalam Gambar 3.

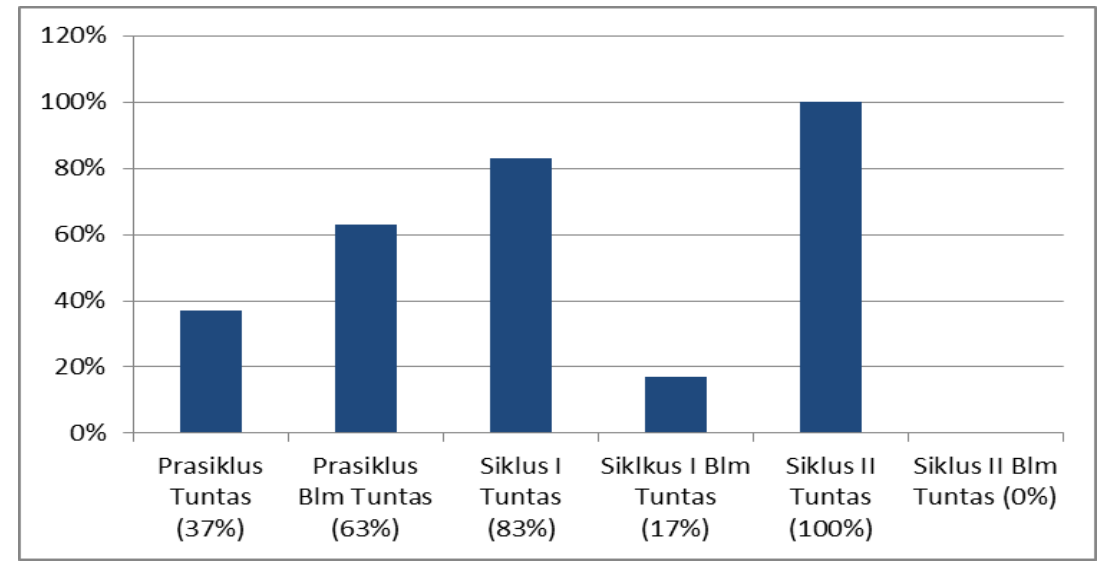

Gambar 3. Grafik Hasil Penelitian Tindakan Kelas

Berdasarkan Gambar 3, penerapan model pembelajaran Cooperative Learning adalah diperoleh nilai rata-rata kelas 77,2 , ketuntasan belajar mencapai $83 \%$ pada siklus I, dan nilai rata-rata 82 , ketuntasan belajar mencapai $100 \%$ pada siklus II. Sehingga dapat disimpulkan model pembelajaran Cooperative Learning pada mata pelajaran bahasa Indonesia dapat meningkatkan hasil belajar siswa kelas XI.IPS SMA Negeri 1 Negara tahun pelajaran 2018/2019.

Model pembelajaran Cooperative Learning merupakan strategi pembelajaran yang menekankan peran aktif siswa belajar dikelas serta mampu menanamkan konsep atau prinsip yang sebelumnya tidak 
diketahuinya dan siswa akan lebih tekun dan asik serta menyenangkan karena dapat menarik perhatian siswa dalam belajar bahasa indonesia (Qusyairi \& Sakila, 2018; Sari et al., 2014; Sunanto et al., 2020). Sehingga, dapat membantu guru dalam upaya meningkatkan hasil belajar siswa untuk mata pelajaran bahasa indonesia.

Pembelajaran dengan menggunakan model Cooperative Learning merupakan salah satu alternatif dan strategi yang tepat untuk mengatasi masalah membelajarkan siswa (Fitri et al., 2020; Ramadhani, 2017; Yuliarni et al., 2013). Model pembelajaran Cooperative Learning mampu mestimulus siswa untuk lebih aktif, lebih semangat dalam belajar serta keterlibatan siswa dalam kegiatan belajar mengajar lebih tinggi, siswa akan lebih cepat memahami materi pelajaran yang dibahas pada saat pembelajaran berlangsung dan tentu menyenangkan, sehingga dapat berpengaruh terhadap hasil akhir pembelajaran yaitu hasil belajar siswa (Aka, 2016; Darmawan, 2014; Said et al., 2019).

Penelitian ini didukung dengan beberapa penelitian yang relevan dengan penelitian ini yaitu, pertama penelitian yang dilakukan oleh (Dewi, 2013), yang memperoleh hasil bahwa penggunakan Model Cooperative Learning teknik marry go round berpengaruh terhadap hasil belajar IPA siswa kelas IV SD. Kedua, penelitian yang dilakukan oleh (Darmawan, 2014), yang memperoleh hasil bahwa pembelajaran multimedia IPA berbasis animasi melalui model Cooperative Learning terbukti dapat meningkatkan kreativitas mahasiswa. Ketiga, penelitian yang dilakukan oleh (Aka, 2016), yang memperoleh hasil bahwa model quantum teaching dengan pendekatan Cooperative Learning terbukti dapat meningkatkan kualitas pembelajaran PKn.

Implikasi penelitian ini adalah mestimulus siswa untuk lebih aktif, lebih semangat dalam belajar serta keterlibatan siswa dalam kegiatan belajar mengajar lebih tinggi, siswa akan lebih cepat memahami materi pelajaran yang dibahas pada saat pembelajaran berlangsung dan tentu menyenangkan.

\section{Simpulan}

Berdasarkan uraian dari hasil penelitian dan pembahasan yang telah dilakukan, maka peneliti dapat menarik kesimpulan bahwa dengan menerapkan model pembelajaran Cooperative Learning pada mata pelajaran bahasa indonesia dapat meningkatkan hasil belajar siswa kelas XI.IPS SMA Negeri 1 Negara tahun pelajaran 2018/2019. Implikasi penelitian ini adalah mestimulus siswa untuk lebih aktif, lebih semangat dalam belajar serta keterlibatan siswa dalam kegiatan belajar mengajar lebih tinggi, siswa akan lebih cepat memahami materi pelajaran yang dibahas pada saat pembelajaran berlangsung dan tentu menyenangkan.

\section{Daftar Rujukan}

Aka, K. A. (2016). Model Quantum Teaching Dengan Pendekatan Cooperative Learning Untuk Meningkatkan Kualitas Pembelajaran PKn. Jurnal Pedagogia, 5(1), 35-46. https://doi.org/10.21070/pedagogia.v5i1.87

Amelia, D. J., \& Saputra, S. Y. (2017). Analisis Kelayakan Buku Siswa Kelas IV Tema Makhluk Hidup Kurikulum 2013. Pedagogia: Jurnal Pendidikan, 6(1), 98-109. https://doi.org/10.21070/pedagogia.v6i1.617

Anggraeni, R., Sulton, S., \& Sulthoni, S. (2019). Pengaruh Multimedia Tutorial Terhadap Hasil Belajar Bahasa Indonesia. Jurnal Kajian Teknologi Pendidikan, 2(2), 96-101. https://doi.org/10.17977/um038v2i22019p096

Asmahasanah, S., Sa'diyah, M., \& Ibdalsyah. (2018). Analisis Keterampilan Mengajar Guru Dan Penanaman Nilai Positif Melalui Pemanfaatan Kebun Sekolah. Sekolah Dasar: Kajian Teori Dan Praktik Pendidikan, 27(2), 167-173. https://doi.org/10.17977/um009v27i22018p167

Darmawan, H. (2014). Peningkatan Kreatifitas Mahasiswa Dalam Merancang Media Pembelajaran Multimedia IPA Berbasis Animasi Melalui Model Cooperative Learning. Jurnal Edukasi, 12(2), 193-204. https://doi.org/10.31571/edukasi.v12i2.155

Dewi, K. E. (2013). Peningkatan Hasil Belajar IPA Menggunakan Model Cooperative Learning Teknik Marry Go Round pada Siswa Kelas IV B SD Negeri Klegung. Jurnal Ilmiah Guru Caraka Olah Pikir Edukatif, 3(4). https://journal.uny.ac.id/index.php/cope/article/view/3002

Faizah, U. (2015). Penerapan Pendekatan Saintifik Melalui Model Project Based Learning Untuk Meningkatkan Ketrampilan Proses Dan Hasil Belajar Siswa Kelas IV SD Negeri Seworan, Wonosegoro. Scholaria: Jurnal Pendidikan Dan Kebudayaan, 5(1), 24-38. https://doi.org/10.24246/j.scholaria.2015.v5.i1.p24-38

Fitri, R., Neviyarni, N., \& Zikri, A. (2020). Pembelajaran PKn Dengan Model Cooperative Learning Tipe Talking Stick Di Sekolah Dasar. Jurnal Basicedu, 4(1), 183-193. 
https://doi.org/10.31004/basicedu.v4i1.322

Kurniasari, F. (2017). Implementasi Pendekatan Saintifik Pada Penugasan Aktivitas Di Buku Teks Bahasa Indonesia Kelas VII SMP Berdasarkan Kurikulum 2013. Jurnal Pendidikan Edutama, 4(1), 9-26. https://doi.org/10.30734/jpe.v4i1.44

Larasati, V., \& Gafur, A. (2018). Hubungan kompetensi pedagogis dan kompetensi profesional guru PPKn dengan prestasi belajar siswa sekolah menengah. Jurnal Civics: Media Kajian Kewarganegaraan, 15(1), 45-51. https://doi.org/10.21831/jc.v15i1.17282

Mulyadin. (2016). Implementasi Kebijakan Pembelajaran Tematik Terpadu Kurikulum 2013 Di SDN Kauman 1 Malang Dan SD Muhammadiyah 1 Malang. Jurnal Edutama, 3(2), 31-48. https://doi.org/10.30734/jpe.v3i2.35

Purwanti, K., AR, M., \& Yusrizal, Y. (2014). Kepemimpinan Kepala Sekolah Dalam Meningkatkan Kompetensi Guru Pada Smp Negeri 2 Simeulue Timur. Jurnal Ilmiah Didaktika, 14(2), 390-400. https://doi.org/10.22373/jid.v14i2.510

Putra, P. A., Agung, A. A. G., \& Sulastri, N. M. (2014). Pengaruh Model Pembelajaran Scramble Berbantuan Media Permainan Teka-teki Silang Terhadap Hasil Belajar Bahasa Indonesia Siswa Kelas V Semester Ganjil Tahun Pelajaran 2013/2014 di SD Negeri 1 Sangsit Kecamatan Sawan Kabupaten Buleleng. Jurnal Mimbar PGSD Universitas Pendidikan Ganesha, 2(1), 1-12. https://doi.org/10.23887/jjpgsd.v2i1.2929

Putri, I. G. A. C. A., Putra, D. K. N. S., \& Zulaikha, S. (2014). Pengaruh Metode Pembelajaran SQ3R Terhadap Hasil Belajar Bahasa Indonesia Kelas V SD. Mimbar PGSD Undiksha, 2(1). https://doi.org/10.23887/jjpgsd.v2i1.2471

Qusyairi, L. A. H., \& Sakila, J. (2018). Pengaruh Model Cooperative Learning Tipe Inside-Outside Circle (IOC) terhadap Prestasi Belajar dengan Memperhatikan Minat Belajar Matematika. Palapa: Jurnal Studi Keislaman Dan Ilmu Pendidikan, 6(1), 34-49. https://doi.org/10.36088/palapa.v6i1.57

Ramadhani, S. P. (2017). Pengaruh Pendekatan Cooperative Learning Tipe (TPS) Think, Pair, and Share Terhadap Hasil Belajar PKn di Sekolah Dasar. Premiere Educandum : Jurnal Pendidikan Dasar Dan Pembelajaran, 7(2), 124-134. https://doi.org/10.25273/pe.v7i2.1653

Said, I. M., Sutadji, E., \& Sugandi, M. (2019). Pengembangan Bahan Ajar Berbasis Cooperative Learning Dengan Pendekatan Saintifik Untuk Siswa Smk Se-Kota Malang Program Keahlian Teknik Ototronik. Jurnal Pendidikan: Teori, Penelitian Dan Pengembangan, 1(2), 265-270. https://doi.org/http://dx.doi.org/10.17977/jp.v1i2.6131

Sari, D. M. (2017). Analysis of Students' Mathematical Communication Ability By Using Cooperative Learning Talking Stick Type. Infinity Journal, 6(2), 183-194. https://doi.org/10.22460/infinity.v6i2.p183-194

Sari, K., Setiyowati, E., \& Indrawati, S. A. (2014). Pengaruh Penerapan Metode Cooperative Learning Model Jigsaw Pada Layanan Bimbingan Klasikal Terhadap Pemahamanself Regulated Learning (Studi Eksperimen Pada Siswa Kelas XI Tata Boga 3 SMK Negeri 30 Jakarta). Insight: Jurnal Bimbingan Dan Konseling, 3(2), 63-69. https://doi.org/10.21009/INSIGHT.032.11

Sukmady, F. W. (2017). Meningkatkan Kemampuan Berempati Anak Usia 5-6 Tahun Melalui Cooperative Learning. Jurnal Penelitian Dan Pengembangan Pendidikan Anak Usia Dini, 4(2). https://doi.org/10.30870/jpppaud.v4i2.4650

Sunanto, R. F., Apriliani, R., \& Nafi'ah, W. (2020). Students' Mathematical Problem Solving Abilities: The Impact of The Co-Op Co-Op Cooperative Learning Model and Missouri Mathematics Project. DESIMAL, 3(3), 279-286. https://doi.org/10.24042/djm.v3i3.7332

Suria, M. D. O., Suwatra, I. W., \& Murda, N. (2019). Pengaruh Model Pembelajaran Snowball Throwing Berbantuan Media Audiovisual terhadap Hasil Belajar Bahasa Indonesia. Jurnal Ilmiah Sekolah Dasar, 3(1), 89. https://doi.org/10.23887/jisd.v3i1.17662

Ulya, F., Rc, A. R., \& Sulistyorini, S. (2020). The Effectiveness of Project-Based Learning Model and Talking stickType of Cooperative Learning Model on the Quran-Hadith Subject Learning Outcomes. Innovative Journal of Curriculum and Educational Technology, 9(2), 87-93. https://doi.org/https://doi.org/10.15294/ijcet.v9i2.40173

Yulia, D. S. F., Wahjoedi, W., \& Sapto, A. (2019). Pengaruh Metode Pembelajaran SQ3R Terhadap Hasil Belajar Bahasa Indonesia. Jurnal Pendidikan, 4(6). https://doi.org/10.17977/jptpp.v4i6.12537

Yuliarni, E., Luawo, M. I. R., \& Karsih, K. (2013). Pengaruh Penerapan Model Cooperative Learning Tipe STAD (Student Teams Achievement Division) Dalam Layanan Bimbingan Klasikal Terhadap Keterampilan Belajar Siswa Dalam Membaca Dengan Teknik SQ3R (Studi Pre-Eksperimen Pada Siswa Kelas X-F Di SMAN 8 Bogor). Insight: Jurnal Bimbingan Konseling, 2(1), 25-31. https://doi.org/10.21009/INSIGHT.021.05 